\title{
Economics, Logistics, and (Human Resources) Management in Military Sciences
}

\author{
Joseph Soeters
}

\section{Contents}

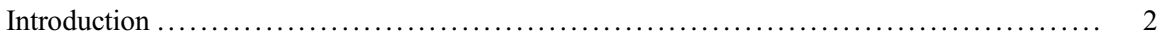

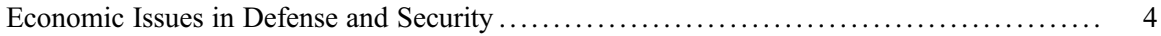

Logistics in the Military, On and Off the Battlefield .............................. 7

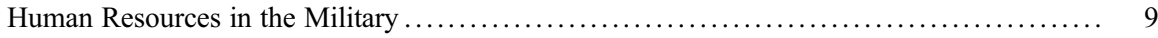

General Managerial Issues in the Armed Forces ................................. 12

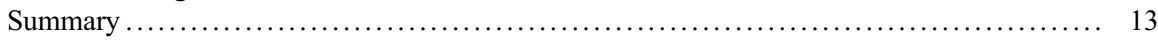

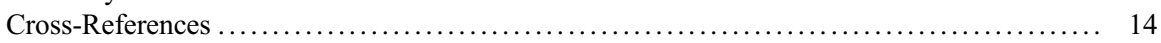

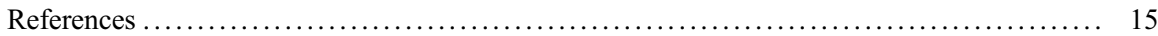

\section{Abstract}

This chapters aims to introduce the section on economics, logistics, and (human resources) management in military sciences. The military is best known for its successes, or the lack thereof, on the battlefield. In this context, topics such as tactics, military leadership, and command and emotions like courage and persistence are often studied. Less well familiar is the idea that military success and defeat are highly dependent on the way the military organization has been structured, prepared, trained, and equipped before the real action starts. Similarly, it is underestimated how much military performance depends on financial means, logistics, and human resources during the action. The idea that economics, logistics, personnel policies, and management are only relevant in peacetime conditions is simply wrong. This chapter uses historical examples and insights from current management theory and research to make this clear, and, at the same time, introduces which topics will be reviewed in the other chapters of the section on management, economics and logistics. These issues play at the national level

Joseph Soeters has retired.

This chapter has profited from comments provided by Paul van Fenema.

J. Soeters $(\bowtie)$

Vught, The Netherlands

(C) The Author(s) 2020 
but certainly also in the international arena where the different allies and competitors meet.

\section{Keywords}

Management $\cdot$ Defense economics $\cdot$ Military logistics $\cdot$ Human resources management $\cdot$ Military organization

\section{Introduction}

Military organizations are among the oldest manifestations of human efforts to deliberately get things done. Long before civilian enterprises and industries took shape, the military demonstrated how buildings could be constructed, ships could be built and navigated, how thousands of men could be disciplined to fight their way forward, and how occupied territories could be governed. The military paved the path toward understanding how strategies and maneuvers, people and material resources, money, and technologies could fit together to reach for ambitious goals. The military set the examples in strategy development, organizing, leadership, engineering, and logistics (Van Creveld 2004; Ahlstrom et al. 2009).

Yet, with the arrival of the industrial revolution, the roles have gradually switched. Whereas, centuries ago, engineers could predominantly be found in the military, they steadily made their entrance in the industries that were newly founded as of the second half of the nineteenth century (Shenhav 2007). These quickly expanding companies also increasingly hired other experts, such as economists, legal and logistics experts, and social and behavioral scientists. Since then, civilian industries and business corporations are in the lead of developing management knowledge, which has enabled the emergence of increasingly sophisticated technical artifacts and services. Since then, the military could can learn from civilian organizations, more - so it seems- than the other way around (De Waard and Soeters 2007; Soeters et al. 2010; Soeters 2020).

Reviewing the role of managerial knowledge for the military, it is often said that management knowledge (including adjacent areas such as legal and economic expertise) is only needed for the military preparing for action, hence the military in peacetime conditions. In such a view, management is associated with rationality, planning, white collar-work, and clean hands, whereas the actions in military operations predominantly require emotional strength, improvisation, dirty hands, and virtues such as courage and heroism. Both assumptions in this view, however, are wrong.

Management in peacetime conditions is also about emotions and simply getting things done, whereas in operations rationality, planning, and office work have always been, and still are, tremendously important. Hence, a first observation to introduce this part of the handbook is that management knowledge is important for the military in both cold and hot conditions. As Brown (1953: 7) formulated this already more than fifty years ago, "Effectiveness of our armed forces in war depends 


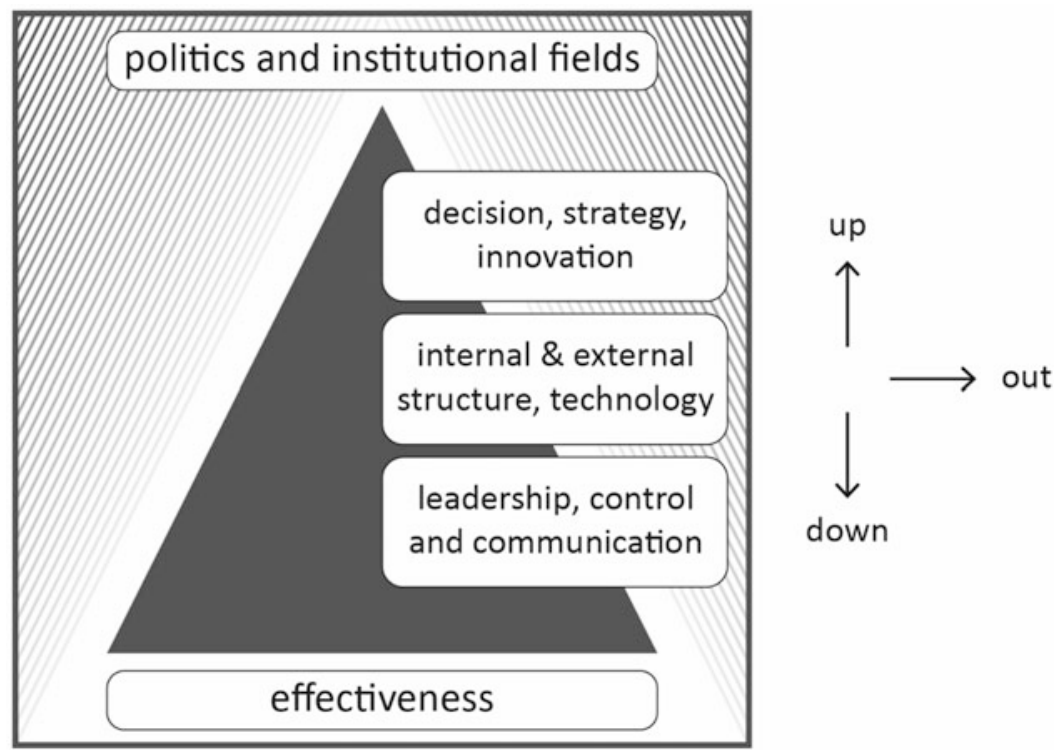

Fig. 1 General overview of (military) organizations. (Derived from Soeters 2020: 7)

upon the effectiveness of our armed forces in peace." We will come to see many illustrations of this observation throughout the various chapters in this part of the Handbook. Perhaps, in the current times, in which technologies and professional skills have become so dominant, warriors turned into managers, so to speak (e.g., Martin 1981).

What do we talk about when we talk about the role of management, economics, and logistics in the military? Figure 1 provides a general overview.

This figure shows that the military organization - like other organizations knows various levels. Usually at the top of the organization, strategic decisions are made about how to prepare for action, how to invest in new technologies and innovations in general, how to use the budget that is available, in which activities to engage, and also how to increase or protect the budget in the political arena (e.g., Brooks 2016). At the middle level, such decisions relate more to everyday practice, in particular, with regard to the build-up of the organization, the procurement of equipment, the supply and maintenance of material resources, cooperation with partners inside and outside the organization, and the introduction and use of new technologies as well as the recruitment and training of personnel. At the bottom level, the everyday realities on and off the field of operations occur, including direct leadership and command, control, and communication. Here, the performance of the material and the human resources, and the interplay between them, are the critical factors.

As any other organization, the military is surrounded by influences from outside. For the military in particular, politics are crucial. In democracies, elected politicians, often without any military experience, decide about the expenditures for the military 
as well about the beginning and ending of military action. Besides, elected politicians make the decisions about what needs to be achieved by the military. As politicians are so important, the military needs to influence them, "manage" them so to speak, which could be called managing up. This process adds to the usual way of managing down one's employees as well as managing out, which refers to collaboration with partners such as contractors, suppliers, and militaries from other services and armed forces from other nations. Multinational military cooperation has become increasingly important over the years, and this development is not likely to come to an end anytime soon. At the end of the day, it is all about military effectiveness, which is reaching the goals that have been formulated before the action was initiated (Peen-Rodt 2012).

All in all, the military is confronted with ensuring and using financial resources, with procuring, using, and maintaining material resources and with recruiting, training, and commanding personnel, the human resources, in the military organization. These are the topics that will be dealt with in the remainder of this introductory chapter. Accordingly, the role of this chapter is to serve as an introduction to the economic, logistical, and managerial issues in military sciences.

\section{Economic Issues in Defense and Security}

The size of the budget has always been the major economic issue the military has to deal with (e.g., Hitch and McKean 1960; Hartley 2018). It also is the most controversial and political one, at least today. While the budget in earlier times - up until the decolonization wars - was as high as it was uncontested, it nowadays has become a major issue. In those earlier times the military itself was undebated, at least most of the times. The military was there to protect the nation against invasions and attacks and, if things went well, it led to conquests and prosperity because large gains could be won through the richness of invaded or colonized regions. Despite occasional criticism, the military at the time had a clear "business model" that was accepted by most.

In current times, however, invasions and colonization have become illegal, and clearly out of fashion. This is not to say such endeavors and the threats thereof no longer exist, but they have become relatively scarce (Pinker 2018: 156 ff.) or take the form of, for instance, diplomatic, information, or economic warfare. In particular, after the demise of the Soviet Union in the 1990s the idea that a new world war was looming had disappeared. Yet, a number of smaller wars emerged - in particular on the Balkans, but also in Africa as well as in Afghanistan and Iraq, and in other parts of the Middle East, such as most recently in Syria. This led to increased requests for military interventions, none of which was without debate, however. Since then, wars of choice have replaced wars of necessity, as it is called. One can discuss choices, not necessities.

This development revealed different views among nations about how menacing actions of other nations are, and what needs to be done about those threats. In the USA worldview, in particular, the planet is full of (potential) enemies and foes, and 
the ambition is to be in the lead of the pack, with the explicit wish to "own the skies." Hence, the US defense budget is of astronomic proportion (about $3.25 \%$ of the national GDP), which due to America's giant economy exceeds the budgets of all other nations by far, including those of China, Russia, and Saudi Arabia, for instance (Hartley 2018: 54). But the US government progressively expresses its annoyance that the US worldview is not adopted by their allies. Such criticism does not primarily pertain to the UK and France, two nations that concur in their emphasis on the usefulness of military solutions and, hence, spend considerable sums on defense and security. In contrast, a number of continental European partners in the NATO alliance have been repeatedly admonished by the US government to increase their budgets for defense and security. Nations such as Germany, the Netherlands, Spain, Belgium, and Italy are pressurized to expand their expenditures up to the level of at least $2 \%$ of their national economies, a level they currently are far from reaching (e.g., Beeres and Bogers 2012; Hartley 2018). After all, says the US government, there are so many threats and dangers waiting to manifest themselves sooner or later. Yet, these dangers and threats are not perceived by all in the same way. Whereas Russia is an eternal, lethal enemy for the US and the UK, for Germany and other continental European nations, it is a nation in the neighbourhood they simply have to live and do business with, despite everything.

In expressing the wish to see their allies create larger defense budgets, the US government is not without self-interest: if allies will raise their budgets for defense and security, most likely major parts of these increases will go to the American weapons industries that for a number of reasons can use every bit of extra money. The US defense budget, although giant, is not unlimited and an increasing part of it goes to domains that are related to human resources, such as veterans' affairs and recruiting costs and wages that need to be competitive with the civilian labor market (Dunlap 2011). Therefore, there is a strain on the American defense budget that prevents the limitless purchase of newly developed and very costly technologies (Dunlap 2011). Given this situation, every F-35 or C-130 sold to foreign governments helps sustain the American weapon industry and, hence, the American economy.

Next to debates about expenditures, there is also discussion about the actual contribution of national troops in the conduct of operations. Some countries, not surprisingly those with the highest budgets, tend to be first in initiating (combat) operations, and some, such as Canada and the Netherlands in Afghanistan, tend to be first to quit the action (Massie 2016). The US and the UK started the various operations in Iraq and Afghanistan that were conducted over the last 30 years; France and the UK were the main initiators of the bombing campaign over Libya in 2011, to which campaign Germany refused to participate. Also, Russia believes in the importance of military power, and acts consequentially, such as most recently in Syria.

The operations in Afghanistan, a new "long war" that started with the assaults on 9/11, led to substantial debates with respect to burden sharing among the allies. It was clear from the beginning that article V of the NATO Treaty would apply: "an attack on one is an attack on all." In response to what happened in New York and 
Washington, the US government without hesitation started operations in Afghanistan, the country where the origins of the attacks could be traced. After quick first results, the operations were expanded with the support of all NATO member-states and several other nations such as Australia. With this, the question of burden sharing among nations emerged. Clearly, the contribution of the US forces was larger than of all other nations taken together. However, as expressed in terms of the relative population size and GDP, the UK contribution was larger. Also, the relative number of casualties of the UK, Denmark, and Canada exceeded the burden of the USA (Bogers and Beeres 2013). All this, of course, says nothing about the effectiveness of the operations: did the operations turn Afghanistan into a safer and better country? After all, that was the goal of the operations from the very beginning.

A final economic issue related to the military concerns of efficiency and control. Other than operational effectiveness, efficiency is about time and money. Whereas effectiveness relates to the question whether or not the goals of an operation have been achieved in the course of actions, efficiency is all about the ratio between input and output. An operation may have been very effective but may have been not efficient at all (because the costs were too high). Also, a mission may have been very efficient (because it was inexpensive), yet may not have reached any of its goals and aims. Effectiveness and efficiency are not the same.

A relatively new development in the military that is related to efficiency concerns is the increased hiring of personnel from Private Military Companies (PMCs). This is often done for political reasons, but also because the expenditures to hire such personnel are flexible and can be terminated as soon as the task, for which PMCs were engaged, is finished. Conventional military personnel produce costs before the job gets done and require expenditures that continue after the operations have ended. Hiring PMCs is based on considerations that immediately relate to efficiency concerns (e.g., Soeters 2020).

General efficiency-related reflections are: How much money has been spent to reach an objective, how much personnel has been deployed, how many vehicles and devices have been purchased and used? And, more importantly, what did the military do with these resources? The latter questions were not raised in historical times, when the military was hardly contested, but these questions have increasingly been put forward in the past decades (e.g., Norheim-Martinsen 2016). The answers to these questions often pertain to the number of patrols (on the ground, at sea, in the air) that were conducted, the number of personnel that were deployed to missions overseas, the number of targets that were bombed, and the exercises that were organized including the size of these exercises. These indicators say a lot about the throughput of the military production process but do not convey a lot about what in fact has been accomplished. Yet, oftentimes these are the best markers of military performance one can produce.

In order to ensure the efficient use of the resources, it is important to have a proper mix of management control instruments. Management control refers to cost control and financial policies as well as to material and human resources management and quality management (e.g., Soeters 2020: 119). Management control and the corresponding concept of accountability have their origins in military academies 
(Hoskin and Macve 1988). It is about making sure that the financial means are properly spent in purchasing processes (and have not been lost due to nepotistic practices or fraud), and that the available resources have been used carefully - no waste, no pollution, no unnecessary abrasion and destruction, no unjustified depreciation of goods.

Management control consists of a mixture of the so-called hard, legal controls and soft, informal controls (Heeren-Bogers 2018). Whereas hard controls relate to cost accounting and the bureaucratic and legal control of transactions, soft controls pertain to behavioral tendencies among leaders and workers to act in accordance with the goals of the organization. This implies, for instance, that commanders need to display concrete behavior in line with what the organization deems fitting. Also, what is expected of personnel needs to be clear and doable, and there should be organizational support for those who want to express their disagreement of what in their eyes is going wrong. For sure, commanders have a large responsibility in realizing suitable soft controls to ensure the proper use of scarce resources, which is the quintessential challenge posed by the economic sciences and also in the military (Heeren-Bogers 2018).

\section{Logistics in the Military, On and Off the Battlefield}

Logistics is perhaps not the sexiest topic to study in the military, but throughout history logistics has proven to be one of the most important elements in the performance of armed forces. Logistics belongs to the field of operations management: getting things done by having raw material at the right time on the right place, process this raw material into ready-to-use, high-quality products or services, and get these products and services where and when they are needed (e.g., Slack and Brandon-Jones 2019). As to the significance of logistics, the military does not differ from firms or companies in the civilian domain.

Battles have been won or lost not so much due to differences in fighting power or combat spirit, but due to variations in the power to get the needed stuff, staff, and information at the right time on the right place, and to sustain this capacity over a longer period of time. Whereas the usual emphasis in military training is on courage, leadership, and tactical proficiency, generals nowadays have learned to speak about tonnage, inventory levels, and supply chains (Immerwahr 2019: 282). Today's generals know what counts in operations nowadays. And they have become good at it.

The Israeli scholar Martin van Creveld stressed the importance of operations management and logistics in his historical overview called "Supplying War" (Van Creveld 2004). He clearly demonstrated how often logistics have been decisive in the final result of military engagements. He also showed that due to technological advancements the distance for the military to operate has become increasingly larger. It went from nearby operations in the times when men and later horses were the main means of transport, to destinations that were much further away when, respectively, sailing, steam machineries, fuel engine technology, and aviation made military 
actions possible over much larger distances. Today, the whole globe is the arena where military action can take place, including the skies, space, and the digital dimension.

The importance of logistics in military action has become perfectly clear in the operations that led to the liberation of Europe, starting with D-Day on 6 June 1944. The landings in Normandy and the following supply chains had a large influence on the success of the allied operations. To stop the ceaseless supply of allied staff and stuff, the troops of Nazi-Germany launched a desperate attack to regain the port of Antwerp in the winter of 1944/1945 - the so-called "Battle of the Bulge." This contra-attack failed not because of a lack of fighting spirit or fire power on the Naziside, but because of an inadequate supply of people and material resources, in particular fuel and ammunition. The attack simply stopped because after a few days there were no more supplies for the Nazi-troops on the right place at the right time (Cole 2015). A contra-attack to stop successful logistics failed because of unsuccessful logistics.

Since then, military logistics has developed further, setting the examples for the advancement of business logistics in commercial firms, today encompassing the movement of people and goods to all places on the globe and back. Today's globalization and advanced logistics go hand in hand. In the military, this has become apparent in the ways the US armed forces operate from all over the world. Immerwahr (2019: 282 ff.) in his book explains how logistical innovations increased the pace of operations, but also enabled the military to move through places without carefully preparing the ground first. Today, the US forces demonstrate that a longdistance network can be operated without seizing large areas or zones. Colonies are no longer needed to deploy all over the world; bases, however, are. The US is very good at maintaining bases, from where they can operate, all over the world, from their own coasts to Africa and Asia, and further across the Pacific back home - or the other way around. To a lesser degree other nations, such as for instance the UK, France, Russia, and China, have similar "warehouses" for forward storage worldwide.

In addition, technological advancements in aviation made planes bigger, more powerful, and capable of covering longer distances, whereas at the same time cargo became smaller. Engines could be delivered in parts, food could be dehydrated, package material lost lots of weight due to the development of plastics, and information could be processed and distributed much quicker, almost real-time nowadays. The newest innovations pertaining to 3D-printing will make cargo even less sizable, as it will be possible to produce spare parts and other necessities right on the spot, in the area of operations.

Nonetheless, the deployment cycle still creates considerable logistics challenges in the supply chain, as the ISAF-mission in the first two decades of the century demonstrated (e.g., Rietjens et al. 2010; Van Kampen et al. 2012). Because this mission required considerable numbers of "boots on the ground," lots of stuff was needed to make the mission legitimate, successful, and acceptable for personnel that could also have chosen any other job than being in Afghanistan. Therefore, military personnel needed to be protected and taken care of properly, in terms of safety, health, food, hygiene, lodging, equipment, and leisure time facilities. This 
necessitated the preparation and transport of many people and substantial tonnages, which was not even the largest challenge. Moving staff and stuff to the mission areas was generally not the hardest thing to do, despite the looming dangers to the flights and convoys. The hardest test perhaps was making sure the stuff was available on the right place at the right time, in sufficient quantities, qualities, and retrievable in the many containers that were sent overseas. It showed that the military was perhaps not as good at the integration of information technology and logistics as major business firms, such as retail chains, already were.

After the mission had ended, everything needed to be redeployed again, and refurbished at the home base. This also required careful planning and it created an additional new challenge. What to do with the stuff, the material resources in the mission area, that was either no longer useable or was too expensive to dismantle and bring back home? As to the latter, buildings and other infrastructure could often be handed over either to the allied militaries that would replace the parting troops or to host-national parties. When the Dutch troops had to leave the Afghan province of Uruzgan in 2010, their base was taken over by the American contingent, whereas other buildings could be used by Afghans.

The former aspect, waste processing, has become more challenging. In historical times, material resources could be looted and left behind as pleased, because that was the burden host-nationals simply had to carry. Remember that most of the objects on display at the British Museum in London are looted or simply taken away from all over the world by British troops and officials. This was a practice that lasted centuries but has nowadays become illegal; it nowadays leads to discussions about returning the objects to the rightful owners.

As to leaving behind goods that are no longer of use, regulations and practices are not as strict, but there is an increasing awareness that military forces that have been deployed are responsible for waste management. This requires cleaning up the area of operations, in whatever ways possible. As said, this is not yet as regulated as stealing properties, but since the Vietnam War, in which chemicals generated damage to the population long after the US troops had left, awareness and sensitivity have increased. But there is still a long way to go to ensure that military logistics also includes care for the host-national population and areas after the operations have come to an end. Sustainability, a hot topic in business logistics, still has to make its way to the military.

\section{Human Resources in the Military}

The next field of application of managerial thinking to the military relates to the study of human resources (HR) in the armed forces. Military force is manpower force, as manpower is traditionally needed to control geographical areas. Today manpower is also increasingly required to operate technological instruments and devices. In particular, since the abolition of conscription, the All-Volunteer military organization needs to compete with other employers, to acquire a sufficient portion 
of an increasingly limited young workforce. The military, after all, has become "just another job" (Moskos and Wood 1988).

In particular, the fact that military work progressively has become technological work including work in the digital dimension introduces a sort of "war on talent" on the labor market. New personnel need to be highly qualified. Traditional bureaucratic organizing and personnel management may no longer be fitting enough to deal with such challenges. Therefore, experiments with newer and more flexible approaches to recruit new specialized personnel, including career and wage differentiation, are needed in military organizations (e.g., Geluk et al. 2020).

This is particularly pressing because for the military, human resources management is an even more urgent matter than it is in conventional civilian organizations: personnel with proper military qualifications cannot be attracted from the external labor market. There are no general educational facilities in society that prepare people to get ready for the military job. The military have to do this by themselves, for which reason they have to maintain their own educational institutions, such as military academies, garrisons, and other training facilities. The military are responsible for all aspects of the Human Resources Cycle.

The HR-cycle includes the recruitment and selection of new personnel, their training, education, and preparation for action as well as their actual performance and the way their performance is guided, controlled, judged, and compensated. In addition, employees' exit, retirement, and care after their departure need to be taken care of (e.g., Dessler 2019).

The very specific character of military work, implying the possible experience and use of large-sized violence, is likely to generate health- and life-related difficulties for at least parts of the military workforce. Besides, the social position and mental health of veterans have always been an important point of concern for the military. After all soldiers on mission have often experienced events and behaviours that are likely to lead to traumatic reactions, even or particularly, after the military job has ended. Another specific aspect of military's human resources relates to the increasing importance of the so-called reserve soldiers, most often retired military but still active (wo)men, who can be called up for duty in missions or other assignments. Such reserve forces have become increasingly important in operations conducted by nations such as the USA, the UK, and Israel (Lomsky-Feder et al. 2008). A chapter elsewhere in this Handbook specifically deals with the reasons behind and the characteristics of the recent rise of reservists' role.

Other than that, there are two topics in connection with military's human resources that attract increasing attention these days. First, connected with the growing significance of women's rights as well as the increasing need for welleducated personnel, women access almost all positions in the military today. For the first time in history, this provides the possibility for the military to really mirror the whole population, and not the male population only. Recently, in fact rather late, also combat positions have been opened up for women, despite the traditional masculine character of such "work." Hence, "female warriors" enter the scene, which seems to trigger the excitement of many men and women, not only of those who design attractive female heroes in computer war games. 
Not so much in relation to combat, but more in the context of peace missions gender-balanced forces are seen as indispensable to attain proper results. The reason for this is simple: peacekeeping requires continuous interaction with the local population and half of the population is female (e.g., Bridgess and Horsfall 2009). Another topic in this connection relates to the work-family balance (e.g., Moelker et al. 2019). The work-family balance is not only of concern for female military personnel but also for the wives of military men who have a professional career of their own, and, of course, for the military men themselves. The recurrent deployment of military personnel puts a burden on the family, a burden that partners often find difficult to carry if they have to take care of children and work at the same time. Increasingly, the military finds itself in a position in which they need to take responsibility for this specific matter in HR management.

The second major topic related to human resources in the military refers to the inclusion of foreigners and minorities in the military. Over the last decades, societies have become more heterogeneous as migrant workers, refugees, and asylum seekers and their families from different regions and religions settled in nations that previously were more used to emigration than immigration. The challenge of including these "newcomers" in the military is also a matter of civil-military relations, as an essential element of democratic governing is that no one should be excluded from civil and military service. Yet, next to these democratic considerations, there are also operational considerations that underline the necessity of including minorities in the military. First, there is of course the shortage in supply of qualified personnel. For this reason, increasingly more nations with an All-Volunteer Force open their armed forces for personnel from designated other countries, where they have the same mother tongue for instance, such as Belgium vis-à-vis France, the Netherlands, and the other EU-countries.

As to the integration of minorities in the armed forces, there are operational reasons as well. In military missions abroad, chances are that the interaction with the host-nation population will be more fluent, subtle, and supple when at least parts of the mission force resemble the people in the area of operations. Bosman and associates (2008) demonstrated how Dutch Muslim soldiers were quite apt in relating to the local population in Muslim mission areas, such as Bosnia, Iraq, and Afghanistan. The presence of a certain "natural" cultural awareness among parts of the troops is also likely to stimulate the much needed cultural awareness and competence among the whole of the mission contingents (e.g., Haddad 2010). This may happen in the same manner as reserve soldiers with their experience in the civilian world are likely to mediate and in fact "soften" the military's - sometimes rough - ways of dealing with people in the areas of operation (e.g., LomskyFeder et al. 2008). This point also connects with the logic of striving toward a more gender-balanced composition of contingents on mission (e.g., Bridgess and Horsfall 2009).

The use of Private Military Companies - a consequence of outsourcing of military activities to organizations that operate on the market - is very much related to efficiency concerns, as we saw before. Here, human resources management, economics, and financial management in the military come together. The use of 
PMCs creates flexibility in military expenditures, which is a very attractive policy option. On the other hand, the practice of using PMCs has been criticized because their activities may evade the command and control of the conventional hierarchical chain in armed forces and may lead to a weakening of the traditional military culture (Soeters 2020; Heinecken 2014). PMCs' work is most and for all guided by the content of contracts. Yet, what is stipulated in contracts often is relatively general and vague, perhaps deliberately so, because formulating specific goals and actions tends to create clear criterions to check what has been done. This is something that politicians oftentimes want to avoid. Actually, this may be something that military and political contract negotiators strive for: flexibility not only in spending but also in the formulation and control of goals and practices.

A last aspect in the domain of HR management is ensuring proper, ethical behavior of the troops, both inside and outside the organization, i.e., to fellowservicemen and women as well as to the people in the area of operation who really experience the actions conducted by the military. This is about preventing - and if needed punishing - all sorts of transgressions (stealing, abusing, and violating other people, their rights and their properties). This requires managing in all directions: down, out, and up. Here again, commanders play a quintessential role as we saw before in our discussion about the importance of soft controls in the military (Schaubroek et al. 2012).

\section{General Managerial Issues in the Armed Forces}

Talking about management in the armed forces is also talking about the structure of the military organization (Soeters 2020: 11-24). Traditionally, the military organization is a specimen of bureaucratic organizing, with a well-defined hierarchical chain of command, a clear division of labor, in which one element is posited in a larger element (such as in the army: squad, platoon, company, battalion, brigade, division), and in which compliance with the rules dominates the organizational culture. This "engineering" set-up dates back to the Roman Empire and before (Van Doorn 1975; Shenhav 2007), and it is likely to be the dominating model in a long time to come.

However, as more flexibility is required, there will be an increasing need to sometimes deviate from such essentials; this may occur, for instance, if a certain mission requires the deployment of a tailored task force combining various traditional elements in one unit. Then, the standard set-up of the force needs to be adapted to what is needed in a specific mission. Additionally, the emphasis on rules will be maintained because this manufactures health, safety, and legal protection, but if the situation demands, personnel are allowed to make decisions that are not strictly in accordance with the rules yet prove to be better. Commands from above need not always be unconditionally accepted, as they may also be discussed by the rank-andfile, particularly before the action. We saw this when talking about the growing importance of soft controls. Occasionally, ethical considerations may supersede rules 
and commands. This is not a standard practice, but such reflections have become more valuable than before, in all organizations and, hence, also in the armed forces.

A second general issue concerns the strategic positioning of the military and military strategic management in general. The figure at the beginning of this chapter showed that the so-called strategic apex of any organization is involved in the formulation and implementation of strategies. This of course also applies to the military, even though politicians have the final word in this decision making. Yet, the military strategic apex may influence what politicians think and do, among other things by demonstrating how much needed they are. This starts with depicting threats all over the world and in all sorts of domains. Threats are oftentimes socially constructed. Portraying many others and their actions as enemies and acts of war $-\mathrm{a}$ process of "hostilization," so to speak - naturally implies there is a large need for the military.

When the budget is sizable enough, this infers that the military will do a lot; from assistance in case of disasters at home, to support civil authorities and health organizations abroad, to the training of foreign militaries, to patrolling on sea to protect commercial ships against pirates, to espionage and intel gathering, to lethal drone operations, to digital warfare, and to straight combat. You name it, the military does it, oftentimes outside of the general public's view. The problem of this tendency is twofold: the request for more budget will never stop and what the military does escapes from the attention of society and even the commanding politicians (Brooks 2016; also: Mazzetti 2013). This concern, related to strategic management in the military, may affect civil-military and political-military relations, even in mature democracies. It is likely to make the military forces more crucial and powerful than is perhaps needed in reality. Be that as it is, the pairing of problems and solutions, of threats and military action, is complex and much more subject to political views and feelings than to academic knowledge.

A final point relates to international management in operations. Military operations nowadays are usually conducted in an international framework because allying with others increases the size, power, and sustainability of operational resources as well as the international legitimacy of the actions. Given the international set-up of most missions today, issues of differences in national strategic cultures and operational styles are likely to come to the fore. If not properly managed, the confluence of national views, interests, and habits will create more misunderstanding and problems than one would wish for (e.g., Soeters 2020: 174-187). Even the simple act of information sharing may be difficult.

\section{Summary}

In this introductory chapter, we have outlined the main themes and challenges that surface in the domain of economics, logistics, and (human resources) management in the armed forces today. Academically, these subjects belong to the field of business economics, business and public administration, organizational sociology, and psychology as well as information technology and engineering, the latter to a certain extent. 
All these academic disciplines are essentially empirical, which means they are focused on researching observable phenomena in everyday reality. In this, they rely on a gamut of methodological tools, with a traditional emphasis on the collection, analysis, and modeling of quantitative data, particularly in engineering, economics and the traditional social and behavioral sciences. Yet, increasingly, qualitative data are valued to comprehend managerial practices and their effects. An example would be the work by Henry Mintzberg, whose insights and findings have been decisively influential while being backed by qualitative data only. His work applies to profit firms as much as it does to military organizations (e.g., Soeters 2020: 78-91). In general, one can state that the standard methodologies and epistemological stances in the managerial sciences pertain to the study of managerial occurrences in the military too (e.g., Deschaux-Dutard 2019). Except for political views and feelings of national pride and pain that - most unfortunately - sometimes permeate the military sciences, there is not a lot of contest about the various ways to study the military.

New developments in the domains of economics, business administration, and social sciences will increasingly rely on big data analysis and model simulations. Big data analysis refers to the study of unstructured data, such as information on internet searches, telephone calls, and the physical movements of people, as much as it pertains to the examination of structured data, such as business transactions (George et al. 2014). It does not require a lot of imagination to see that this development will be important for the study of the military and their operations, too (Soeters 2020: 169).

This introduction intended to pave the path for four more chapters that are broader and at the same time more in-depth, each focusing on the different elements of this part of military sciences. It will show that it is hardly possible to exaggerate the importance of these topics. Without proper management, logistics, and (human resources) management it is impossible to conduct successful military operations and bring them to a satisfactory end. Increasingly, military's performance depends on managerial knowledge and practices, in the broadest sense of these words.

\section{Cross-References}

- Behaviour Economics

- Challenges in HRM in Military Organizations

Defence Management and Economics

- Dynamic Intersection of Military and Society

- Hybrid Organizing

- Management, Economics and Logistics in Military Sciences

- Military Behaviour and Ethics

- Military Design

- Military Psychology

- Military Sociology

- Rationality and Irrationality in Military Organizing

- Strategy and Doctrine

- The Role of Operational Research in Military Personnel Management 


\section{References}

Ahlstrom, D. D., Lamond, \& Ding, Z. (2009). Reexamining some management lessons from military history. Asia Pacific Journal of Management, 26(4), 617.

Beeres, R., \& Bogers, M. (2012). Ranking the performance of European armed forces. Defence and Peace Economics, 23(1), 1-16.

Bogers, M., \& Beeres, R. (2013). Mission Afghanistan: Who bears the heaviest burden? Peace Economics, Peace Science and Public Policy, 19(1), 32-55.

Bosman, F., Ait bari, F., \& Soeters, J. (2008). Dutch Muslim soldiers during peace operations in Muslim societies. International Peacekeeping, 15(5), 695-705.

Bridgess, D., \& Horsfall, D. (2009). Increasing operational effectiveness in UN peacekeeping. Towards a gender-balanced force. Armed Forces \& Society, 36(1), 120-130.

Cole, H. M. (2015). The Ardennes: Battle of the Bulge. Scotts Valley: CreateSpace Independent Publishing Platform.

De Waard, E., \& Soeters, J. (2007). How the military can profit from management and organization science. In G. Caforio (Ed.), Social sciences and the military. An interdisciplinary overview (pp. 181-196). London/New York: Routledge.

Deschaux-Dutard, D. (2019). Methods in defence studies. In D. J. Galbreath \& J. R. Deni (Eds.), Routledge handbook of defence studies (pp. 40-50). London/New York: Routledge.

Dessler, G. (2019). Human resource management, global edition (16th ed.). Harlow etc: Pearson Education.

Dunlap, C. J. (2011). The military-industrial complex. Daedalus, 140(3), 135-147.

Geluk, P., Schlueter, M., Thomas, T., \& Erkens, S. (2020). Fixing the talent gap in armed forces worldwide. Boston Consulting Group: Amsterdam etc.

George, G., Haas, M. R., \& Pentland, A. (2014). Big data and management: From the editors. Academy of Management Journal, 57(2), 321-326.

Haddad, S. (2010). Teaching diversity and multicultural competence to French peacekeepers. International Peacekeeping, 17(4), 566-577.

Hartley, K. (2018). Defence budgets. In D. J. Galbreath \& J. R. Deni (Eds.), Routledge handbook of defence studies (pp. 53-71). London/New York: Routledge.

Heeren-Bogers, J. (2018). Control with care. The value of soft controls in the management control system of the Dutch Defence Organization. Ph.D. thesis. Rotterdam: Erasmus University.

Heinecken, L. (2014). Outsourcing public security: the unforeseen consequences for the military profession. Armed forces \& Society, 4(4), 625-646.

Hoskin, K. W., \& Macve, R. H. (1988). The genesis of accountability: The West Point Connection. Accounting, Organizations and Society, 13(1), 37-73.

Immerwahr, D. (2019). How to hide an empire. A short history of the greater United States. London: Vintage.

Lomsky-Feder, Gazit, N., \& Ben-Ari, E. (2008). Reserve soldiers as transmigrants: Moving between the civilian and military worlds. Armed Forces \& Society, 34(4), 593-614.

Martin, M. (1981). Warriors to managers. The French Military Establishment since 1945. Chapel Hill: The University of North Carolina Express.

Massie, J. (2016). Why democratic allies defect prematurely: Canadian and Dutch unilateral pullouts from the war in Afghanistan. Democracy and Security, 12(2), 85-113.

Mazzetti, M. (2013). The way of the knife. The CIA, a secret army, and a war at the ends of the Earth. New York: Penguin.

Moelker, R., Andres, M., \& Rones, N. (Eds.). (2019). The politics of military families. State, work organizations, and the rise of the negotiated household. London/New York: Routledge.

Moskos, C., \& Wood, F. (Eds.). (1988). The military, more than just a job? Washington, DC etc: Pergamon-Brassey's.

Norheim-Martinsen, P. M. (2016). New sources of military change - Armed forces as normal organizations. Defence Studies, 16(3), 312-326. 
Peen-Rodt, A. (2012). Successful conflict management by military means. Ethnopolitics, 11(4), 376-391.

Pinker, S. (2018). Enlightenment now. The case for reason, science, humanism, and progress. London: Penguin.

Rietjens, B., Van Kampen, T., \& Grant, T. (2010). Logistics planning and control. Lessons learned in Afghanistan. In J. Soeters, P. C. van Fenema, \& R. Beeres (Eds.), Managing military organizations. Theory and practice (pp. 97-110). London/New York: Routledge.

Schaubroek, J. M., Hannah, S. T., Avolio, B. J., Kozlowski, S. W. J., Lord, R. G., Treviño, L. K., \& Peng, A. C. (2012). Embedding ethical leadership within and across organization levels. Academy of Management Journal, 55(5), 1053-1078.

Slack, N., \& Brandon-Jones, A. (2019). Operations management (9th ed.). Harlow, etc: Pearson Education.

Van Doorn, J. A. A. (1975). The soldier and social change. Comparative studies in the history and sociology of the military. Beverly Hills/London: Sage.

Van Kampen, T., van Fenema, P., \& Grant, T. (2012). Getting there and back. Long-distance military logistics with customers in mind. In R. Beeres, J. van der Meulen, J. Soeters, \& A. Vogelaar (Eds.), Mission Uruzgan. Collaborating in multiple coalitions for Afghanistan (pp. 47-63). Amsterdam: Amsterdam University Press.

\section{Further Reading}

Brooks, R. (2016). How everything became war and the military became everything. Tales from the Pentagon. New York: Simon \& Schuster.

Brown, A. (1953). The armor of organization. New York: Hibbert Printing Cy.

Hitch, C. J., \& McKean, R. N. (1960). The economics of defense in the nuclear age. Santa Monica: Rand.

Shenhav, Y. (2007). Manufacturing rationality. The engineering foundations of the managerial revolution. New York: Oxford University Press.

Soeters, J. (2018). Sociology and military studies. Classical and current foundations. London/New York: Routledge.

Soeters, J. (2020). Management and military studies. Classical and current foundations. London/New York: Routledge.

Soeters, J., Van Fenema, P. C., \& Beeres, R. (Eds.). (2010). Managing military organizations. Theory and practice. London/New York: Routledge.

Van Creveld, M. (2004). Supplying war. Logistics from Wallenstein to Patton (2nd ed.). New York: Cambridge University Press.

Open Access This chapter is licensed under the terms of the Creative Commons Attribution 4.0 International License (http://creativecommons.org/licenses/by/4.0/), which permits use, sharing, adaptation, distribution and reproduction in any medium or format, as long as you give appropriate credit to the original author(s) and the source, provide a link to the Creative Commons license and indicate if changes were made.

The images or other third party material in this chapter are included in the chapter's Creative Commons license, unless indicated otherwise in a credit line to the material. If material is not included in the chapter's Creative Commons license and your intended use is not permitted by statutory regulation or exceeds the permitted use, you will need to obtain permission directly from the copyright holder. 